\title{
Ptolemy's Britain and Ireland: A New Digital Reconstruction
}

\author{
Corey Abshire, ${ }^{\mathrm{a}}$ Anthony Durham, ${ }^{\mathrm{b}}$ Dmitri A. Gusev, ${ }^{\mathrm{c}}$ and Sergey K. Stafeyev ${ }^{\mathrm{d}}$ \\ ${ }^{a}$ Data Science, Indiana University, Bloomington, Indiana, U.S.A.; dcabshir@indiana.edu \\ ${ }^{b}$ Computer Consultant and Technical Writer, Greenwich, United Kingdom; anthony.durham@ntlworld.com \\ ${ }^{c}$ Computer and Information Technology, Purdue University, Columbus, Indiana, U.S.A.; dgusev@purdue.edu \\ ${ }^{d}$ VNIIGeoSystem, Moscow, Russia; staff1@mail.ru
}

\begin{abstract}
In this paper, we expand application of our mathematical methods for translating ancient coordinates from the classical Geography by Claudius Ptolemy into modern coordinates from India and Arabia to Britain and Ireland, historically important islands on the periphery of the ancient Roman Empire. The methods include triangulation and flocking with subsequent Bayesian correction. The results of our work can be conveniently visualized in modern GIS tools, such as ArcGIS, QGIS, and Google Earth. The enhancements we have made include a novel technique for handling tentatively identified points. We compare the precision of reconstruction achieved for Ptolemy's Britain and Ireland with the precisions that we had computed earlier for his India before the Ganges and three provinces of Arabia. We also provide improved validation and comparison amongst the methods applied. We compare our results with the prior work, while utilizing knowledge from such important ancient sources as the Antonine Itinerary, Tabula Peutingeriana, and the Ravenna Cosmography. The new digital reconstruction of Claudius Ptolemy's Britain and Ireland presented in this paper, along with the accompanying linguistic analysis of ancient toponyms, contributes to improvement of understanding of our cultural cartographic heritage by making it easier to study the ancient world using the popular and accessible GIS programs.
\end{abstract}

Keywords: Claudius Ptolemy, Ancient geography, GIS analysis, Historical cartography, Georeferencing

\section{Introduction}

This paper presents results of a continuation of our multiyear research of Claudius Ptolemy's classic Geography, a uniquely rich ancient work that provides coordinates of more than 6,300 places known to the celebrated astronomer and geographer. These places include cities, towns, villages, markets, harbors, capes, bays, islands, mountains, lakes, river mouths, estuaries, sources, confluences and bends, etc. Ptolemy's catalog also gives us useful descriptions and other important data, such as the knowledge of which points lie along the shorelines, and which ones are located in the mainland interior. Names of many tribes that once populated the vast expanses of Europe, Africa, and Asia are provided as well, albeit without numerical coordinates. In this work, we expand application of our mathematical methods initially developed to investigate Ptolemy's India and Arabia (Abshire et al. 2016, 13-34; Abshire et al. 2016, 133-154) to Albion and Hibernia, the modern Great Britain and Ireland, historically significant islands once situated on the outskirts of the ancient Roman Empire. A review of the scientific literature related to the analysis of Ptolemy's Britain and Ireland is provided in the next section.

Despite the overall abundance of information contained in Ptolemy's impressive catalog, the tasks of GIS visualization, analysis, and interpretation of the historical data remain difficult for modern researchers. This difficulty is primarily due to the distortions introduced because of misunderstandings of the true shape of the known world by the ancient sources, and is also caused by the compilative nature of Ptolemy's work. A lot of effort is needed to decipher the treasure trove of data and present it in a modern form that makes it more readily accessible to the reader. The important first step toward solving this problem is made by identifying and georeferencing as many ancient locations mentioned by Ptolemy as possible. In Ptolemy's Albion and Hibernia, $170+$ of such locations are found, including some potential duplicates. To put this number into perspective, Ptolemy's Taprobane (Sri Lanka) and India before the Ganges comprised $450+$ data points with coordinates, while the three provinces of Ptolemy's Arabia - Arabia Petraea, Arabia Deserta, and Arabia Felix - contributed $300+$ points. The task of point identification and georeferencing will be discussed in the third section of the paper, along with the linguistic analysis aspect of our reconstruction.

The fourth section of the paper will introduce an extension of our approach to handling the category of tentatively identified points. This category was introduced in our work on Ptolemy's Arabia (Abshire et al. 2016, 133-154), along with a separate category for duplicates.

In the fifth section of our work, we compare the precision of reconstruction achieved for Ptolemy's Britain and Ireland with the precisions that we had computed earlier for his Arabia and India before the Ganges.

Figures 1-4 provide a visual representation of our results achieved for Ptolemy's Britain and Ireland. We draw 
conclusions and outline the future research directions in the final section.

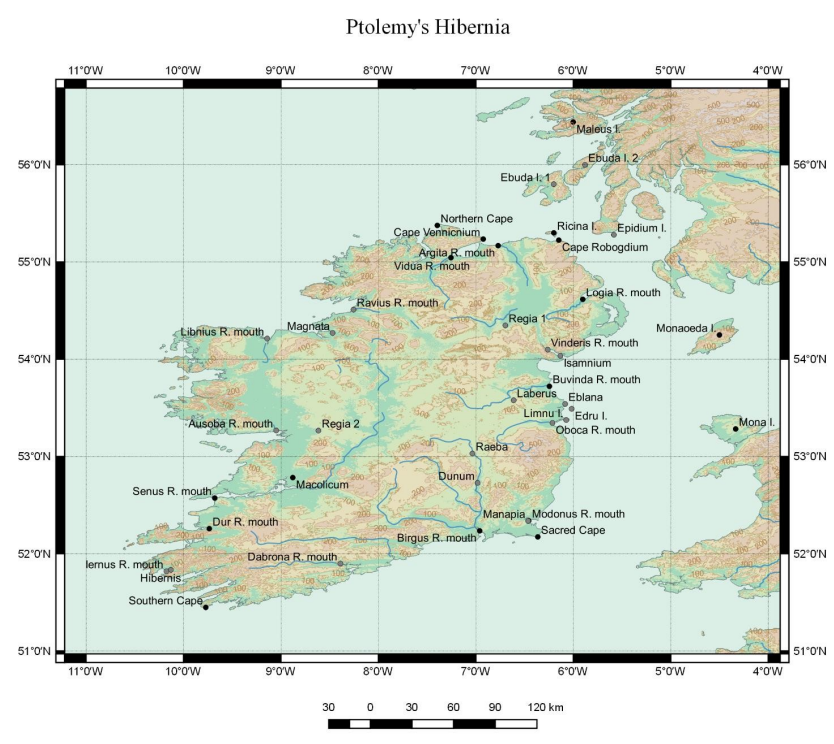

Fig. 1. Ptolemy's Hibernia (Ireland). Tentatively identified points are shown in gray at the coordinates set before data processing.

\section{Literature Review}

Stückelberger and Grasshoff (2006) delivered the best available complete translation of Ptolemy's classic Geography into a modern European language (German). An authoritative Greek version of the original text produced by thorough comparison of several extant Greek manuscripts is included as well. We have used the electronic database of coordinates that came with the book. The unique object IDs assigned by Stückelberger and Grasshoff are adopted here. Stückelberger and Grasshoff also suggest modern names for many locations mentioned by Ptolemy. It is worth noting that the only complete English translation of Geography by E. L. Stevenson (Ptolemy 1991) is well known to be of poor quality (Diller 1935). We still used this imperfect source as part of our effort to translate the German names of objects into English, with some latinisation, in an attempt to undo Ptolemy's “interpretatio graeca" of Latin names.

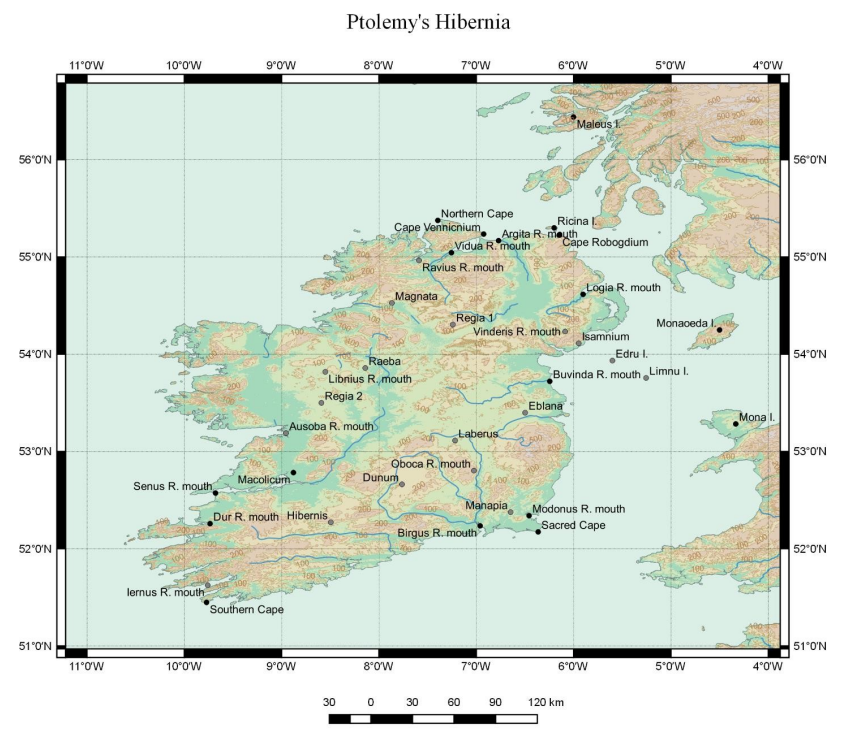

Fig. 2. Ptolemy's Hibernia (Ireland). Tentatively identified points are shown in gray at the coordinates computed using triangulation.

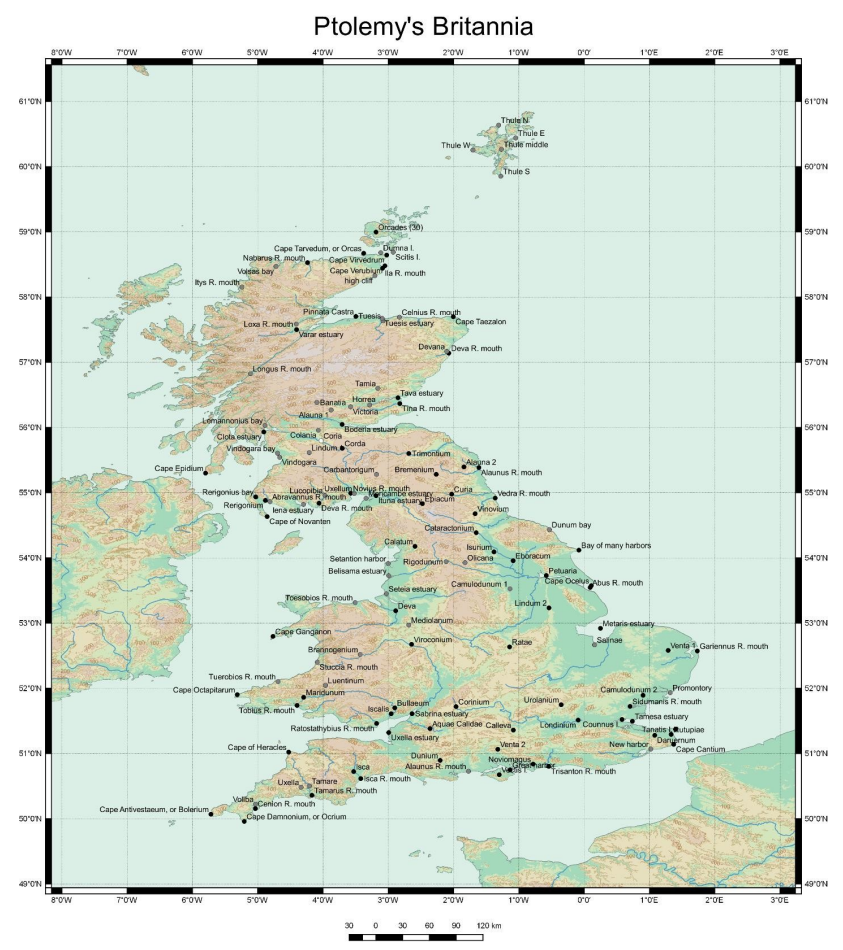

Fig. 3. Ptolemy's Albion (Great Britain). Tentatively identified points are shown in gray at the coordinates set before data processing. 


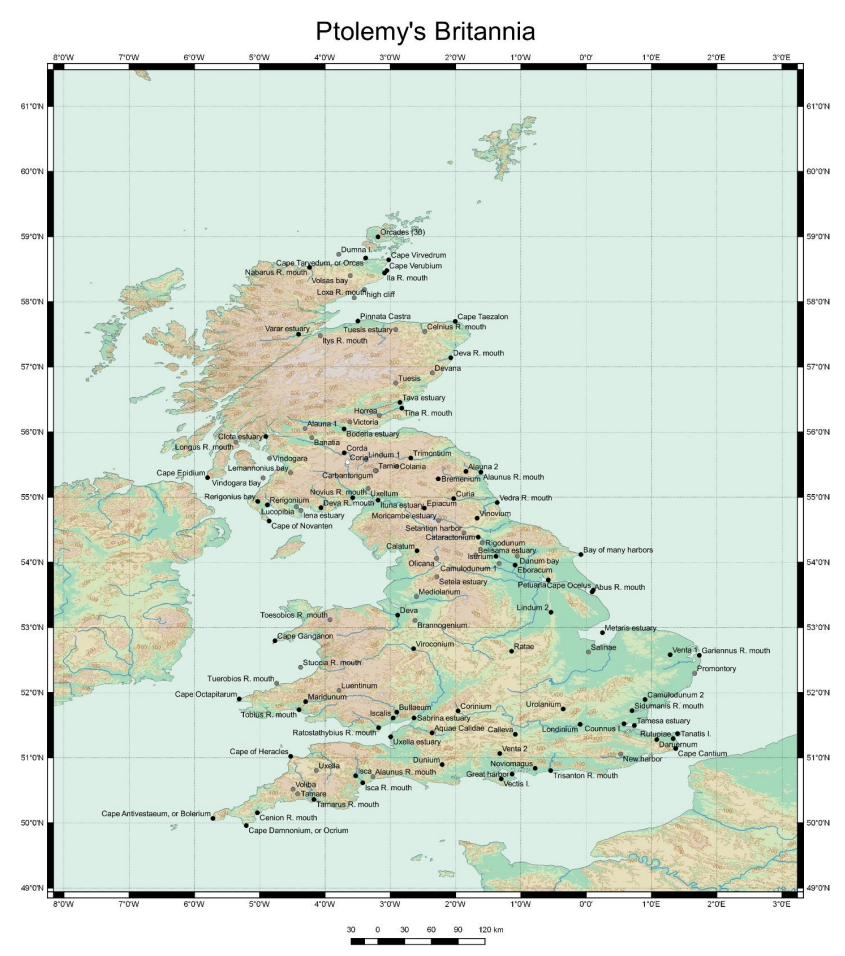

Fig. 4. Ptolemy's Albion (Great Britain). Tentatively identified points are shown in gray at the coordinates computed using triangulation.

Two other significant sources for point identification were (Talbert 2000) and (Åhlfeldt 2017). However, the lack of certainty, along with especially poor coverage in Hibernia, led us to heavy reliance upon a new, highly detailed analysis published online by one of our coauthors (Durham 2017). In addition to extensive linguistic research of Ptolemy's toponyms, the analysis involves comparison of Ptolemy's data to those from other relevant ancient sources, such as the Antonine Itinerary (Cuntz 1929), Tabula Peutingeriana (Levi and Levi 1978), and the Ravenna Cosmography (Schnetz 1942). The analysis revisits such important earlier modern works as (Rivet and Smith 1979) and (Kleineberg et al. 2012). While the space limitation imposed on this paper does not allow us to discuss the results of the comparison in detail, for the benefit of the readers we show the map reconstructions of Great Britain as described in the Antonine Itinerary and the Ravenna Cosmography in Figures 5-6. (Tabula Peutingeriana matches the Antonine Itinerary pretty well, except for few points, such as Serduno, Condecor, Vindovala, Onno, Celunno, Brocoliti, Velurtion. All of them are found on Hadrian's Wall and well established.)

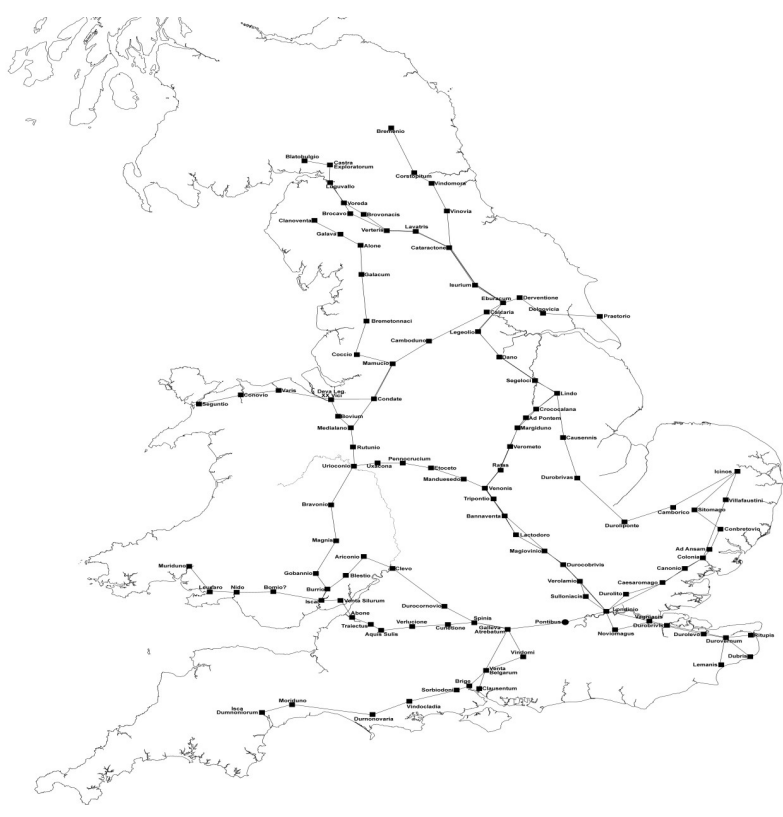

Fig. 5. Great Britain in the Antonine Itinerary.

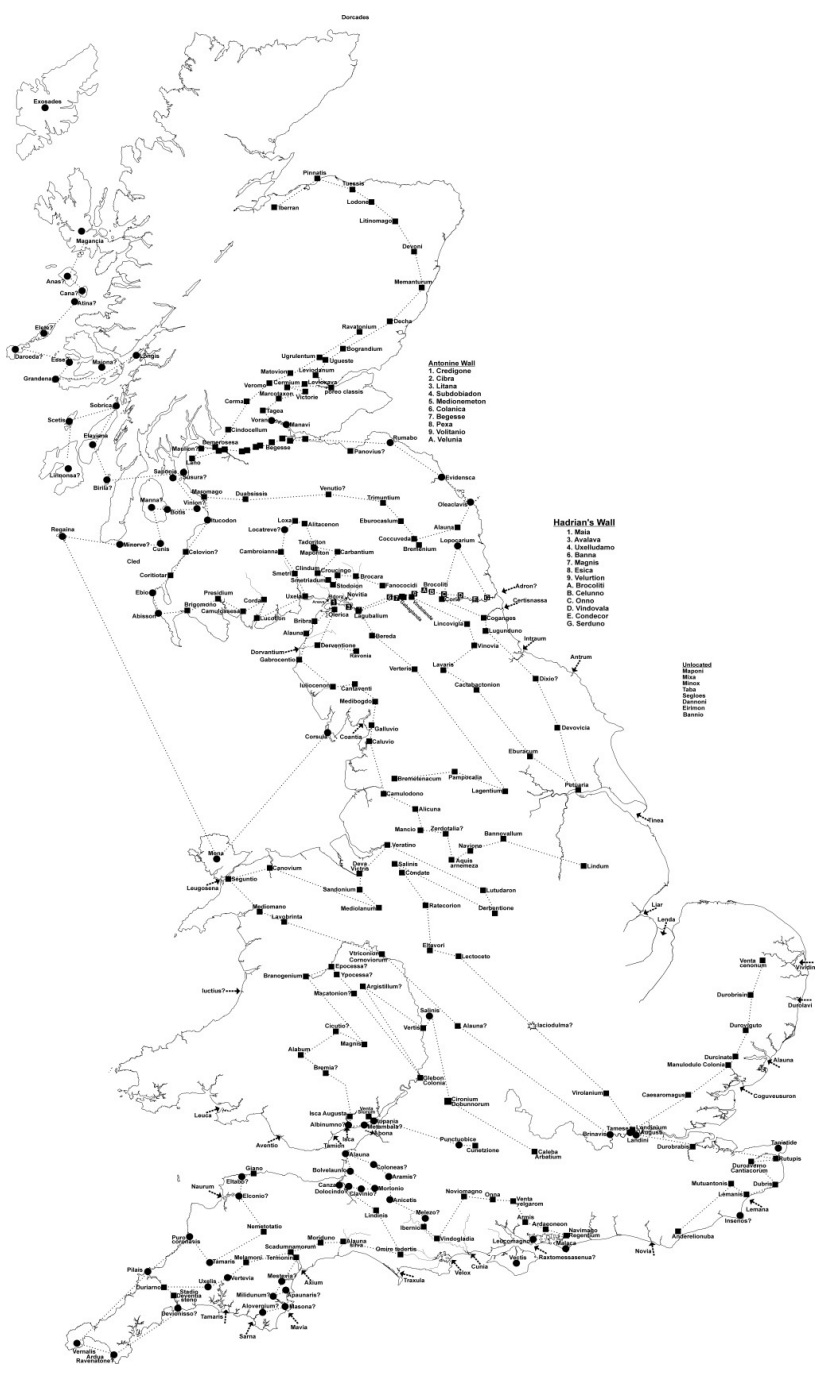

Fig. 6. Great Britain according to the Ravenna Cosmography. 
Strang (1998) subdivided Ptolemy's points for Britain into groups according to two longitudinal scales and several spatially non-intersecting rotation groups to account for the turning of Scotland and other distortions. The modern map contours were then warped to superimpose them over Ptolemy's points. This georeferencing process yielded an approximate reconstruction of Ptolemy's map of Britain in Ptolemy's own projection. In our opinion, this variety of reconstruction is less illuminating than remapping of Ptolemy's points into a modern projection.

Darcy and Flynn (2008) used a relatively primitive mathematical method to produce their digital reconstruction of Ptolemy's Hibernia, which, in absence of a sound statistical analysis of the errors involved, led them to such surprising mistakes as their misidentification of the River Shannon as Ptolemy's Dur (Duris) River, instead of the nearly universally accepted Senus River. Hickson (1894) spotted survival of the Irish name Bun-abhainn-dur 'end of the river Dur' on the River Lee estuary near Derrymore, a rural district of County Kerry, so we have no doubt as to the true identities of the Senus and Dur rivers. Darcy and Flynn provided a very useful table that summarized scholarly identifications of Ptolemy's Irish locations by numerous other sources.

Tsorlini (2011) produced a comprehensive catalogue of Ptolemy's Mediterranean and Black Sea region, along with an original methodology for deriving modern coordinates.

\section{Point Identification and Linguistic Analysis}

Identification of Ptolemy's points is often achieved relatively easily by matching ancient names to their modern counterparts, provided that the names did not change beyond recognition as time passed by. Maridunum (the modern Carmarthen) and Londinium (London) are good examples of such easy matches. It is worth noting that sometimes the names move. For example, the modern Moroccan town of Asilah was mistaken by Stückelberger and Grasshoff (2006) for Ptolemy's Zilia colonia in Mauretania Tingitana. They were unaware that French archaeologists had found altars with inscriptions that let them identify the ruins at Dchar Jdid located $12 \mathrm{~km}$ away from Asilah and previously thought to be Ad Mercurio as Iulia Constantia Zilil (Lenoir 2005). In addition, sometimes the names do change a lot. For example, Ptolemy's Petuaria was positively identified as the modern Brough-on-Humber in Britain thanks to the finding of a dedication stone of the Roman theatre there. The stone recorded the gift of a proscenium stage to the civic settlement at Petuaria by some Marcus Ulpius Januarius.

Information about the ancient roads found in the Antonine Itinerary, Tabula Peutingeriana, and the Ravenna Cosmography can sometimes be very helpful. For example, Mamucio of the Antonine Itinerary and Mantio of the Ravenna Cosmography can both be comfortably identified as Manchester, given their position in the road network. However, the temptation to place
Ptolemy's Brannogenium at the Roman Metchley Fort in Edgbaston, $4.3 \mathrm{~km}$ away from the center of Birmingham, should be resisted, its Ravenna Cosmography counterpart Branogenium being the next stop north from Magnis (the modern Kenchester). This opens up the possibilities that Brannogenium was located at Leintwardine (Rivet and Smith 1979) or further north, at Caersws. Our triangulation and flocking methods place Brannogenium $9 \mathrm{~km}$ apart, within 8.5 and $11.5 \mathrm{~km}$ from Nantwich, 15.0 and $6.2 \mathrm{~km}$ from Middlewich (the ancient Salinae), and 13.0 and $6.3 \mathrm{~km}$ from Warmingham, a place documented in the Domesday Book of 1086 and situated $200 \mathrm{~m}$ away from the remains of a Roman road. These results do not allow us to make a certain identification.

A good example where linguistic analysis can provide some guidance has to do with two places named Camulodunum in Ptolemy's Albion. Camulodunum-2 is well known to be Colchester, while the location of Camulodunum-1 remains uncertain. In our opinion, it makes best sense to translate camulus as 'small hill', cf. Latin cumulus ('heap'), tumulus ('mound'). The word dunum meant a 'fort' or 'walled town'. It was apparently borrowed into Latin from another language, given that Latin texts started mentioning place names containing dunum after Caesar marched into Gaul. One possibility is that Ptolemy's Camulodunum-1 is a corruption of Camboduno, a name from of the Antonine Itinerary that may fit the Roman fort at Slack, near Huddersfield. Here the initial Camb- is referring to curvature, like a camber, cf. Latin camurum, from camur ('arched'). Other possible options include Castle Hill at Almondbury and Burghwallis Roman fort located near the place where the Roman road from Doncaster to Tadcaster crossed the River Skell. A far less likely option is that Camulodunum is the same place as the Antonine Itinerary's Dano (now Doncaster), a river fort. Our triangulation and flocking algorithms place Camulodunum-1 $33.5 \mathrm{~km}$ apart, near Cattal and Baildon, respectively. Cup-and-ring stones on Baildon Moor have shown evidence of inhabitation since Bronze Age.

\section{Handling Tentatively Identified Points}

Comparing distances from several tentative locations of objects from Ptolemy's Geography to approximate placements computed by triangulation and flocking with Bayesian correction represents a novel intuitive modification of the approach introduced in (Abshire et al. 2016, 13-34; Abshire et al. 2016, 133-154). The best example of this analysis bearing fruit is our identification of Ptolemy's New Harbor (Kaivos $\Lambda \mu \eta \nu)$ in Albion. Kleineberg et al. (2012) proposed to identify it as Newhaven in East Sussex, at the mouth of the River Ouse, while Åhlfeldt (2017) preferred a latinised form of the name (Novus Portus) and a location at the end of a Roman road in Hove, near Portslade-bySea. Our triangulation and flocking methods place New Harbor $10.6 \mathrm{~km}$ apart, 55 to $65 \mathrm{~km}$ east from Hove, 45 to $55 \mathrm{~km}$ away from Newhaven, and only 24 to $34 \mathrm{~km}$ west from the modern Lympne, which was known in antiquity as Portus Lemanis, or simply Lemanae. Given that the 
settlement formerly known as Meeching became Newhaven only after 1790 , when a new outlet to sea (The Cut) was built there, we can confidently conclude that the harbor at Lympne was considered new when Ptolemy's source documented it under the name Kavvo $\Lambda \mu \mu \eta$.

In Hibernia, Camden (1607) identified Ptolemy's Raeba as Castlereban, the site of the medieval barony of Rheban, featuring remnants of a castle and a nearby moat. However, our triangulation and flocking algorithms point at locations within 13 to $42 \mathrm{~km}$ from Rathcroghan, a complex of archaeological sites identified as Cruachan, the ancient capital of the Connachta, approximately 120 $\mathrm{km}$ away from Castlereban.

The limitations imposed on the size of this paper do not allow us to discuss more examples of identifications.

\section{Precision Analysis}

In our previous paper (Abshire et al. 2016, 13-34) we expressed anticipation that the precision of our methods for numerical prediction in other regions might surpass those achieved in India before the Ganges. The error histograms for the take-one-out known point predictive analysis using the flocking model with Bayesian adjustment for Hibernia, Albion, Arabia Petraea and India before the Ganges shown in Figure 7 below confirm our prediction.
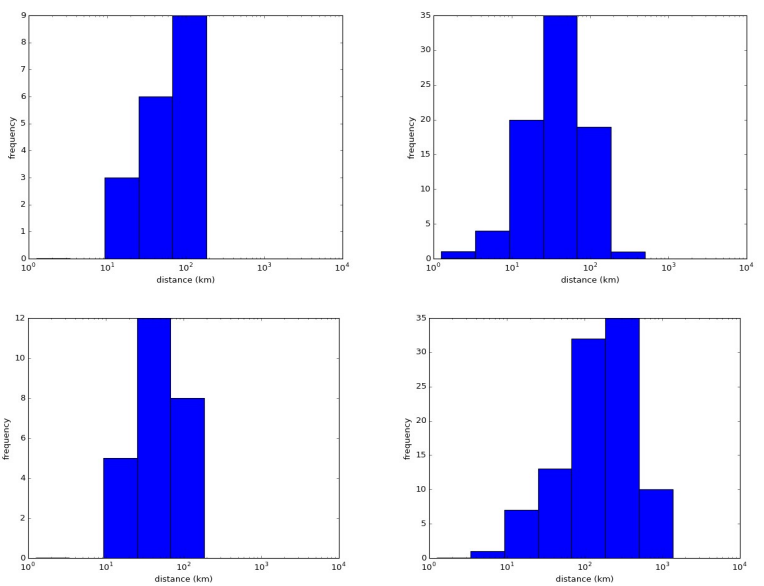

Fig. 7. Error histograms for Hibernia (left top), Albion (right top), Arabia Petraea (left bottom) and India before the Ganges (right bottom) for the flocking model with Bayesian adjustment. (Arabia and India Source: Abshire et al. 2016, 133-154)

\section{Conclusions and Future Work}

We added a new intuitive modification to our approach to handling of tentatively identified points using computational methods for numerical analysis of historical data from Ptolemy's Geography and extended the methods' application to Britain and Ireland. This achievement allowed us to complete the additional region-to-region comparison of predictive performances of our two models (triangulation and flocking with Bayesian adjustment). In another new development, we compared our results for Ptolemy's Albion to the valuable information found in such ancient sources as the Antonine Itinerary, Tabula Peutingeriana, and the
Ravenna Cosmography. Our new digital reconstruction of Claudius Ptolemy's Britain and Ireland presented in this paper, along with the accompanying linguistic analysis of ancient toponyms, helps us improve understanding of our historical cartographic heritage by exploring Ptolemy's oikouménē (the "known world") with readily available GIS tools, such as ArcGIS, QGIS, and Google Earth.

In the future, we intend to apply our methods to more regions from Ptolemy's Geography, while refining further our novel techniques for GIS analysis and visualization of historical data.

\section{Acknowledgements}

This work was partially supported by Google Geo Education Award and Google Maps Engine Grant.

\section{References}

Abshire, C., Gusev, D.A., Papapanagiotou I., \& Stafeyev, S.K. (2016). A Mathematical Method for Visualizing Ptolemy's India in Modern GIS Tools. e-Perimetron, 11(1), 13-34.

Abshire, C., Gusev, D.A., \& Stafeyev, S.K. (2016). Enhanced Mathematical Method for Visualizing Ptolemy's Arabia in Modern GIS Tools. In Proceedings of the 11th ICA Conference on Digital Approaches to Cartographic Heritage (pp. 133-154). Riga, Latvia: International Cartographic Association.

Åhlfeldt, J. (2017). Digital Atlas of the Roman Empire. http://dare.ht.lu.se/. Accessed 1 March 2017.

Camden, W. (1607). Britannia, sive florentissimorum Regnorum Angliæ, Scotiæ, Hiberniæ, et Insularum adiacentium ex intima antiquitate chorographica descriptio: nunc postremo recognita, plurimis locis magna accessione adaucta, \& Chartis chorographicis. London: Georgii Bishop and Joannis Norton.

Cuntz, O. (1929). Itineraria Romana, Vol. 1: Itineraria Antonini Augusti et Burdigalense. Leipzig, Germany: Teubner.

Diller, A. (1935). Review of Stevenson's translation. Isis, 22(2), 533-539.

Durham, A. (2017) Roman Era Names of Forts, Settlements, Rivers, Islands, Tribes, etc. http://www.romaneranames.uk/. Accessed 1 March 2017.

Hickson, M. (1894). Old Place-Names and Surnames (Continued). The Journal of the Royal Society of Antiquaries of Ireland Fifth Series, 4(3), 256-263.

Kleineberg, A., Marx, C., \& Lelgemann, D. (2012). Europa in der Geographie des Ptolemaios. Die Entschlüsselung des "Atlas der Oikumene" Zwischen Orkney, Gibraltar und den Dinariden. Darmstadt, Germany: Wissenschaftliche Buchgesellschaft.

Lenoir, E. (2005) La ville romaine de Zilil du Ier av IVe siècle ap. J.-C., dans L'afrique romaine, Iersiècle av. J.C - début Ve siècle ap. J.-C., colloque de la SOPHAU. Pallas, 68, 65-76. 
Levi, A., \& Levi, M. (1978). La Tabula Peutingeriana. Bologna, Italy: Edizioni Edison.

Ptolemy, C. (1991). Claudius Ptolemy, The Geography. Translated and edited by E. L. Stevenson. New York, NY: Dover Publications, Inc.

Rivet, A.L.F., \& Smith, C. (1979). The Place-Names of Roman Britain. London, United Kingdom: Batsford.

Schnetz, J. (1942) Itineraria Romana, Vol. 2: Ravennatis Anonymi cosmographia et Guidonis geographica. Stuttgart, Germany: Teubner.

Strang, A. (1998). The Analysis of Ptolemy's Geography. The Cartographic Journal, 35(1), 27-47.

Stückelberger, A., \& Grasshoff, G. (2006). Klaudios Ptolemaios: Handbuch der Geographie, GriechischDeutsch. Basel, Switzerland: Schwabe Verlag.

Talbert, R. J. A. (ed.) (2000). Barrington Atlas of the Greek and Roman World. Princeton, NJ: Princeton University Press.

Tsorlini, A. (2011). Claudius Ptolemy "Geōgrafikē Yfēgēsis" (Geographia): digital analysis, evaluation, processing and mapping the coordinates of Greece, the Mediterranean and the Black Sea, based on 4 manuscripts and 15 printed editions, from Vaticanus Urbinas Gr. 82 (13th cent.) until today: the new Catalogue "GeoPtolemy- $\theta$ ". http://digital.lib.auth.gr/record/128272. Accessed 1 March 2017. 